\title{
Contribution of Palli Daridro Bimochon Foundation Activities on Socio-Economic Development of the Beneficiaries in Bangladesh
}

\author{
M.M. Islam ${ }^{1 *}$, M.A.Baree ${ }^{2}$, M.S. Ali ${ }^{3}$, M.M.Rahman ${ }^{4}$, M.S.U.Talukder ${ }^{5}$ \\ ${ }^{1 *} J o i n t$ Director, Palli Daridro Bimochon Foundation, Head office, Mirpur-2, Dhaka-1216, \\ Bangladesh. ${ }^{2}$ Associate Professor, Department of Crop Science and Technology, University of Rajshahi, \\ Bangladesh. ${ }^{3}$ Professor, Department of Agricultural Extension \& Information System, Sere-e-Bangla \\ Agricultural University, Dhaka, Bangladesh. ${ }^{4}$ Managing Director, Palli Daridro Bimochon Foundation, Head \\ Office, Mirpur-2, Dhaka, Bangladeash. ${ }^{5}$ Deputy Director, Palli Daridro Bimochon Foundation, Head Office, \\ Mirpur-2, Dhaka, Bangladesh.
}

\begin{abstract}
The main purpose of the study was to determine the contribution of socio-economic development of the beneficiaries through PDBF activities. The study was conducted in Bhaluka upazila under Mymensingh district, Serpur upazlia under Bogra district and Bhairab upazila under Kishoreganj district. A total number of 338 beneficiaries were finally selected which constituted the sample of the study by using stratified random sampling technique. Fourteen selected characteristics of the beneficiaries were considered as the independent variables and socio-economic development of the beneficiaries through PDBF activities was the dependent variable of the study. Face to face interview schedule was used to collect relevant data from the respondents. Socio-economic development of the respondent was measured by the addition of the extent of changes occurred in 11 selected dimensions of PDBF activities. Data indicated that change in socio-economic development ranges of the respondents varied from 7 to 23 and the average change was 16.37. An overwhelming majority (94.08\%) of beneficiaries belonged to medium, compared to $5.33 \%$ and $0.59 \%$ belong to low and high change in socio-economic development categories respectively. Results of this study indicated that out of 14 variables, the correlation coefficient of 8 independent variables i.e. family size, group cohesion, credit received, credit repayment behavior, training exposure, income generating activities, adoption of innovations and attitude towards PDBF were found significantly related with the dependent variable and another 6 variables i.e. age, education, farm size, savings behavior, credit received, participation with PDBF had no relationship with change in socio-economic development. The study also revealed that the corresponding F-value (14.324) was found highly significant. The above mentioned facts indicated that all the selected independent variables jointly exhibited a multiple correlation $R=0.619$ and corresponding $R^{2}$ value is 0.384 , which means that all the independent variables jointly explained $38.40 \%$ of total variation changes in socio-economic development of the respondents.
\end{abstract}

Keywords: Contribution, PDBF, Socio-economic development.

\section{Introduction}

In Bangladesh, socio-economic development has been the major focus of policy by a large number of GOs, national and international NGOs. Among them, PDBF has launched various activities for socio-economic development in 44 districts of Bangladesh. Micro credit is playing a significant role in socio-economic development, especially poverty reduction by improving households, economic status, increasing living standards, empowering rural women, creating self-employment and ensuring better education and healthcare (Hashemi et al., 1996; Rahman 1999; Chowdhury et al., 2005; Haque and Harbin 2009). Globally, micro credit has become a major technique in the last three decades in providing collateral-free loans to the poor. It is playing a significant role in alleviating poverty (Chowdhury et al., 2005; Ahlin and Jiang 2008; Barboza and Trejos 2009; Kotir and Obeng-Odoom 2009), socio-economic development (Mallick 2002; Ahlin and Jiang 2008), women empowerment (Hashemi et al., 1996; Mayoux 1998; Kabeer 2001; Chowdhury et al., 2005; Osmani 2007; Omorodion 2007; Kotir and Obeng-Odoom 2009), household economic upliftment, and creating alternative livelihoods (Omorodion 2007; Hossain and Knight 2008; Hasan et al., 2009; Kotir and ObengOdoom 2009; Ray-Bennett 2010). At least 45 million people in Bangladesh, almost one third of the population, live below the poverty line, and a significant proportion of them live in extreme poverty. The poverty rate is highest in rural areas, at $36 \%$, compared with $28 \%$ in urban centers. Many people have an inadequate diet and suffer from periods of food shortage. Half of all rural children are chronically malnourished and $14 \%$ suffer from acute malnutrition (Source: IFAD, 2012). Bangladesh is a least developing country of which more than $80 \%$ people live in rural areas. Women constitute almost half of the total population of the country (Sultana et al., 2010). But it is a matter of regret that rural women are economically dependent and vulnerable, educationally backward as well as politically and socially disadvantaged (Sarkerand Rahman, 2007). Palli 
Daridro Bimochon Foundation (PDBF) is the premier socio-economic development organization of the country. It has been trying to improve the well-being of the rural people through institution buildings, human resources development, transfer of technologies and capital formation etc. PDBF has made substantial contribution to an increase in agricultural production, poverty alleviation through productive employment, income generation and social service improvement. Keeping these views in mind, this study was undertaken considering the following objectives: i) To determine and describe some selected characteristics of PDBF beneficiaries; and ii) To explore the contribution of selected characteristics of the beneficiaries to their socio-economic development as perceived by them.

\section{Methodology}

The study was undertaken in three upazilas namely Bhaluka upazila under Mymensingh district, Serpur upazlia under Bogra district and Bhairab upazila under Kishoreganj district. All the group members organized by Palli Daridro Bimochon Foundation (PDBF) of the 3 selected upazilas were considered as the locale of the study. The numbers of PDBF beneficiaries were 2767, 3450 and 2229 in Bhaluka, Serpur and Bhairab upazilas respectively. Thus, a total of 8446 beneficiaries of PDBF of these 3 selected upazilas constituted the population of the study. By taking $4 \%$ of the population a total of 338 PDBF beneficiaries were selected proportionate randomly as the sample of the study. Data were collected personally by the researcher himself in a face to face condition with the individual respondent by using interview schedule. The data collection took six months from September, 2011 to February, 2012.

\section{Measurement of variable}

Age, education, family size, farm size, savings behavior, group cohesion, credit received, credit utilization, credit repayment behavior, participation with PDBF, training exposure, income generating activities, adoption of innovation, and attitude towards PDBF activities were considered as the independent variable of the study. Age of the respondents was measured in terms of years on the basis of his/her response. The age of the respondents were measured in terms of actual years from his/her birth to the time of interview. A score of 0.5 was assigned to those who could sign their name only. A score of zero (0) was assigned to illiterate respondents. Family size of a respondent could be measured by assigning a score of one for each member of the family. Farm size was estimated on the basis of the cultivated area either owned by a farmer or cultivated on share cropping. Savings behavior was measured as regularly, occasionally, seldom and not at all bases. Nine items scale was considered to measure group cohesion. The score of group cohesion of the respondent could range from ' 0 ' to ' 27 '. Credit received was measured to the amount of money received of last 3 years by a respondent as loan from any institutional source or no institutional source. It was expressed in ' 000 ' Taka. Credit utilization behaviors of the respondent were measured by the percentage of loan used for assigned purposes. Four types of repayment behavior was considered for this study treated as regular, irregular, default and not at all basis and the scores of respondents could range from 0 to 3 . Organizational participation with PDBF was measured by adding, the scores after multiplying by duration of participation (year) for all types of membership. Training exposure was measured by the total number of days of training received by the respondent under different training programs. Income generating activities were measured on their nature of participation in different income generating activities as frequently, occasionally, seldom and no participation. Adoption of innovation of a responded was measured on the basis of the degree of adoption of 8 selected improved agricultural technologies and the score of a respondent could range from ' 0 ' to ' 24 . Attitude towards PDBF activities were measured by constituting of 14 statements ( 7 positive and 7 negative). The scores of respondents could range from 0 to 56.

Contribution of PDBF activities on socio-economic development of the beneficiaries was considered as the only dependent variable of the study. Measurement of overall socio-economic development of the beneficiaries through PDBF activities was determined by summing the changes scores for all the 11 selected dimensions before and after involvement with PDBF. For the convenience of calculation and description, the following formula was used for determining the contribution of socio-economic development of the beneficiaries through PDBF activities.

$$
Y=Y_{1}+Y_{2}+Y_{3}+Y_{4}+Y_{5}+Y_{6}+Y_{7}+Y_{8}+Y_{9}+Y_{10}+Y_{11}
$$

Where, $Y=$ score of socio-economic development of the beneficiaries through PDBF activities; $Y_{1}=$ change in participation of women empowerment; $\mathrm{Y}_{2}=$ change in awareness on social issues: $\mathrm{Y}_{3}=$ change in sanitation condition; $\mathrm{Y}_{4}=$ change in drinking water sources: $\mathrm{Y}_{5}=$ change in household water sources; $\mathrm{Y}_{6}=$ change in the treatment of diseases; $\mathrm{Y}_{7}=$ change in ability to bear family expenses; $\mathrm{Y}_{8}=$ change in the dressing habit; $\mathrm{Y}_{9}=$ change in housing condition; $\mathrm{Y}_{10}=$ change in wealth possession $\mathrm{Y}_{11}=$ change in participation in health activities. Thus, the possible range of the impact of socio-economic development scores of the beneficiaries through PDBF activities could range from ' 0 ' to '33' where, ' 0 ' indicated "no development" and ' 33 ' indicated "very high development". 


\section{Results and Discussion}

\section{Selective characteristics of the PDBF beneficiaries}

Some of the salient features such as measuring unit, possible range and observed range, mean, standard deviation (SD), co-efficient of variation (CV) of these 14 selected characteristics (age, education, family size, farm size, savings behavior, group cohesion, credit received, credit utilization, credit repayment behavior participation with PDBF, training exposure, income generating activities, adoption of innovations, and attitude towards PDBF of the beneficiaries have been presented in Table 1.

Table1: Measuring unit, possible range and observed range, SD and CV of the selected characteristics of the respondent beneficiaries

\begin{tabular}{|l|l|c|c|c|c|c|}
\hline \multicolumn{1}{|c|}{ Characteristics } & \multicolumn{1}{c|}{$\begin{array}{c}\text { Measuring } \\
\text { unit }\end{array}$} & $\begin{array}{c}\text { Possible } \\
\text { range }\end{array}$ & $\begin{array}{c}\text { Observed } \\
\text { range }\end{array}$ & Mean & SD* & CV* \\
\hline Age & No. of years & - & $20-55$ & 36.27 & 8.20 & 22.61 \\
\hline Education & Schooling (years) & - & $0.50-16$ & 3.79 & 3.51 & 92.61 \\
\hline Family Size & No. of person & - & $2-8$ & 4.16 & 1.33 & 31.97 \\
\hline Farm Size & Size in hectares & - & $0.004-3.50$ & 0.13 & 0.26 & 200.00 \\
\hline Savings Behavior & Scale score & - & $1-3$ & 2.88 & 0.34 & 11.81 \\
\hline Group Cohesion & Scale score & - & $7-27$ & 19.94 & 3.99 & 20.01 \\
\hline Credit Received & '000' Taka & - & $19-126$ & 65.10 & 22.97 & 35.28 \\
\hline Credit Utilization & '000' Taka & - & $40-100$ & 91.89 & 10.24 & 11.14 \\
\hline Credit Repayment Behavior & Scale score & $1-3$ & $1-3$ & 2.86 & 0.42 & 14.69 \\
\hline Participation with PDBF & Scale score & - & $0-71$ & 14.61 & 12.16 & 83.23 \\
\hline Training Exposure & No. of days & - & $0-90$ & 3.47 & 6.37 & 183.57 \\
\hline Income Generating Activities & Scale score & $0-24$ & $0-24$ & 10.88 & 6.89 & 63.33 \\
\hline Adoption of Innovations & Scale score & $0-56$ & $0-56$ & 46.09 & 4.92 & 10.67 \\
\hline Attitude toward PDBF & Scale score & SD* Standard deviation, CV*=Co-efficient of variation & & \\
\hline
\end{tabular}

\section{Change in socio-economic development}

Respondent's participation in PDBF programme has played a vital role in changing their socio-economic condition. Salient features such as possible range and observed range, mean, standard deviation (SD), coefficient of variation (CV) of the dimensions of the beneficiaries have been presented in Table 2 .

Table 2: Possible range, observed range, mean, standard deviation and co-efficient of variation (CV) change in socio-economic development after involvement with PDBF

\begin{tabular}{|l|c|c|l|c|c|c|c|}
\hline \multicolumn{1}{|c|}{ Characteristics } & $\begin{array}{c}\text { Possible } \\
\text { range }\end{array}$ & $\begin{array}{c}\text { Observed } \\
\text { range }\end{array}$ & \multicolumn{1}{|c|}{$\begin{array}{c}\text { Categories of } \\
\text { characteristics }\end{array}$} & $\%$ & Mean & SD & CV \\
\hline $\begin{array}{l}\text { Change in socio- } \\
\text { economic } \\
\text { development }\end{array}$ & $0-33$ & $7-23$ & $\begin{array}{l}\text { No Change (0) } \\
\text { Low Change (1-11) } \\
\text { Medium Change (12-22) } \\
\text { High Change (>22) }\end{array}$ & $\begin{array}{c}5.00 \\
94.08 \\
0.59\end{array}$ & 16.37 & 2.76 & 16.86 \\
\hline
\end{tabular}

Change in socio-economic development of the respondent through PDBF activities was found to range from 7 to 23, the average was 16.37 with standard deviation 2.76 and co-efficient of variation 16.86. Data furnished in indicated that an overwhelming majority $(94.08 \%)$ of the respondents felt under medium change in socioeconomic development while $5.33 \%$ and $0.59 \%$ fell under low and high change in socio-economic development. Interestingly, it was found that $95 \%$ respondents got opportunity to change their socio-economic development after involving themselves with different activities of PDBF.

\section{Contributions of selected characteristics of the beneficiaries on their socio-economic development}

Fourteen characteristics of the beneficiaries were selected as the independent variables and contribution of PDBF activities on socio-economic development of the beneficiaries through PDBF activities was the dependent variables of this study.

The relative contribution of 14 selected characteristics of the respondents with the impact of socioeconomic development (Full model)

In this study, 14 independent variables were run to determine their contribution. Data presented in the Table 3 indicated that multiple $\mathrm{R}$ and $\mathrm{R}^{2}$ values in full model regression were 0.619 and 0.384 respectively. The corresponding F- value (14.324) was found highly significant. The above mentioned facts indicated that all the selected independent variables jointly exhibited a multiple correlation $R=0.619$ and corresponding $R^{2}$ value is 0.384 , which means that all the independent variables jointly explained $38.40 \%$ of total variation of the changes in socio-economic development of the respondents. 
Table 3: Regression analysis showing the standardized regression co-efficient indicating contribution of the respective independent variables on the dependent variable

\begin{tabular}{|c|c|c|c|c|}
\hline Selected characteristics & $\begin{array}{l}\text { Unstandardized co- } \\
\text { efficient (B) }\end{array}$ & $\begin{array}{c}\text { Standardized } \\
\text { co-efficient (Beta) }\end{array}$ & $\mathrm{t}$ & Sig. \\
\hline Age & 0.016 & 0.049 & 0.950 & 0.343 \\
\hline Education & 0.021 & 0.027 & 0.564 & 0.573 \\
\hline Family Size & 0.201 & 0.097 & 2.092 & 0.037 \\
\hline Farm Size & 0.000 & 0.003 & 0.072 & 0.942 \\
\hline Savings Behavior & -0.263 & -0.032 & -0.696 & 0.487 \\
\hline Group Cohesion & 0.081 & 0.117 & 2.322 & 0.021 \\
\hline Credit Received & 0.000 & -0.002 & -0.050 & 0.960 \\
\hline Credit Utilization & -0.009 & -0.034 & -0.704 & 0.482 \\
\hline Credit Repayment Behavior & 3.136 & 0.471 & 8.788 & 0.000 \\
\hline Participation with PDBF & -0.009 & -0.039 & -0.749 & 0.454 \\
\hline Training Exposure & 0.035 & 0.080 & 1.716 & 0.087 \\
\hline Income Generating Activities & 0.056 & 0.031 & 0.592 & 0.554 \\
\hline Adoption of Innovations & 0.031 & 0.081 & 1.523 & 0.129 \\
\hline Attitude toward PDBF & 0.070 & 0.124 & 2.464 & 0.014 \\
\hline \multicolumn{5}{|c|}{$\mathrm{R}=0.619$} \\
\hline \multicolumn{5}{|c|}{ R Square $=0.384$} \\
\hline \multicolumn{5}{|c|}{ Adjusted R Square $=0.357$} \\
\hline \multicolumn{5}{|c|}{ Std. Error of the Estimate $=2.21354$} \\
\hline \multicolumn{5}{|c|}{ F value $=14.324$} \\
\hline \multicolumn{5}{|c|}{$P=000$} \\
\hline \multicolumn{5}{|c|}{$* * * \mathrm{P}<0.001$ level, $* * \mathrm{P}>0.01$ level, $* \mathrm{P}<0.05$ level } \\
\hline
\end{tabular}

The relative contribution of 8 significant variables after correlation of the respondents with the contribution of socio-economic development (Full model)

Out of 14 selected characteristics family size, group cohesion, credit repayment behavior, participation with PDBF, training exposure, adoption of innovation, attitude towards PDBF were found to exert positive and significant contribution of socio-economic development through PDBF activities. On the other hand, savings behavior, credit received, credit utilization and participation with PDBF exerted negative contribution and rests of the variables (age, education, farm size and income generating activities) have no significant contribution on the socio-economic development through PDBF activities. In this study, 8 independent variables which had significant variables were run to determine their contribution. Data presented in the Table 4 indicated that multiple $\mathrm{R}$ and $\mathrm{R}^{2}$ values in full model regression were 0.616 and 0.379 respectively. The corresponding F-value (25.062) was found highly significant. The above mentioned facts indicated that all the selected independent variables jointly exhibited a multiple correlation $R=0.616$ and corresponding $R^{2}$ value is 0.379 , which means that all the independent variables jointly explained $37.90 \%$ of total variation changes in socio-economic development of the respondents through PDBF activities. Out of 8 selected characteristics (significant variables after correlation) family size, group cohesion, credit repayment behavior, training exposure, adoption of innovations, attitude towards PDBF were found to exert positive and significant contribution to the contribution of socio-economic development through PDBF activities. On the other hand, credit received and income generating activities has no significant contribution on the socio-economic development through PDBF activities (Table 4).

Table 4: Regression analysis showing the standardized regression coefficients indicating contribution of the respective independent variables on the dependent variable

\begin{tabular}{|c|c|c|c|c|}
\hline $\begin{array}{c}\text { Characteristics of PDBF } \\
\text { beneficiaries }\end{array}$ & $\begin{array}{l}\text { Unstandardized } \\
\text { Coefficients (B) }\end{array}$ & $\begin{array}{c}\text { Standardized } \\
\text { Coefficients (Beta) }\end{array}$ & $\mathbf{t}$ & Sig. \\
\hline (Constant) & 1.014 & & 0.753 & 0.452 \\
\hline Family Size & 0.203 & $0.098^{*}$ & 2.231 & 0.026 \\
\hline Group Cohesion & 0.082 & $0.117^{*}$ & 2.379 & 0.018 \\
\hline Credit Received & 0.001 & 0.008 & 0.185 & 0.853 \\
\hline Credit Repayment Behavior & 3.050 & $0.458^{* * *}$ & 9.008 & 0.000 \\
\hline Training Exposure & 0.038 & $0.088^{*}$ & 1.988 & 0.048 \\
\hline
\end{tabular}




\begin{tabular}{|c|c|c|c|c|}
\hline Income Generating Activities & 0.058 & 0.032 & 0.642 & 0.522 \\
\hline Adoption of Innovations & 0.033 & 0.086 & 1.775 & 0.077 \\
\hline Attitude toward PDBF & 0.068 & $0.121^{*}$ & 2.479 & 0.014 \\
\hline \multicolumn{5}{|c|}{$R=0.616$} \\
\hline \multicolumn{5}{|c|}{$\mathrm{R}$ Square $=0.379$} \\
\hline \multicolumn{5}{|c|}{ Adjusted R Square $=0.364$} \\
\hline \multicolumn{5}{|c|}{ Std. Error of the Estimate $=2.20102$} \\
\hline \multicolumn{5}{|c|}{ F value $=25.062$} \\
\hline \multicolumn{5}{|c|}{$\mathrm{P}=0.000$} \\
\hline$* * * \mathrm{P}<0.001$ level, $* * \mathrm{P}>0.0$ & & & & \\
\hline
\end{tabular}

Step-wise regression analysis of all the 14 independent variables on the dependent variable

Step-wise regression analysis of all the 14 independent variables (Table 5) revealed that the variable credit repayment behavior has emerged as the single-most outstanding contributor in explaining variability $(31.90 \%)$ of contribution on socio-economic development followed by attitude towards PDBF (2.20\%), training exposure $(1.10 \%)$, family size $(0.09 \%)$, group cohesion ( 0.09$)$ and adoption of innovations $(0.09)$.

Table 5: Step-wise regression analysis of all the fourteen independent variables on the dependent variable

\begin{tabular}{|l|c|c|c|c|r|r|}
\multicolumn{1}{|c|}{ Selected characteristics } & $\begin{array}{c}\text { Unstandardized } \\
\text { Coefficients (B) }\end{array}$ & $\begin{array}{c}\text { Standardized } \\
\text { Coefficients }\end{array}$ & $\mathbf{t}$ & Sig. & R Square & $\begin{array}{c}\text { R Square } \\
\text { Change }\end{array}$ \\
\hline Credit Repayment Behavior & 3.128 & 0.470 & 9.954 & 0.000 & 0.319 & 0.319 \\
\hline Attitude toward PDBF & 0.068 & 0.120 & 2.484 & 0.013 & 0.340 & 0.022 \\
\hline Training Exposure & 0.037 & 0.086 & 1.958 & 0.051 & 0.351 & 0.011 \\
\hline Family Size & 0.207 & 0.099 & 2.278 & 0.023 & 0.360 & 0.009 \\
\hline Group Cohesion & 0.082 & 0.118 & 2.408 & 0.017 & 0.369 & 0.009 \\
\hline Adoption of Innovations & 0.038 & 0.099 & 2.227 & 0.027 & 0.379 & 0.009 \\
\hline a. Dependent Variable: Impact; Total $=0.379$ & & & & & \\
\hline
\end{tabular}

All the above 6 independent variables jointly explained $37.90 \%$ of the total variation of contribution on socioeconomic development activities (i.e. the dependent variable). Out of this $37.90 \%$ explained variance, the two independent variables i.e. credit repayment behavior and attitude towards PDBF contributed 34.10\%, signifying that these two are the most dominant contributing variables affecting contribution on socio-economic development through PDBF activities of the beneficiaries as a result of PDBF intervention.

Direct and Indirect Contribution of Independent Variables (selected characteristics) of the beneficiaries (path analysis)

Path coefficient analysis was employed in order to obtain clear understanding of the direct and indirect effects of selected independent variables.

\section{Direct and indirect effects of the predictors}

In the present study, path analysis was done to have clear understanding of direct and indirect effects of selected 6 variables which were enter into the stepwise regression model on socio-economic development through PDBF activities. Variable through which substantial indirect effects were channeled were also explored. The 'path coefficients' of selected independent variables with respect to socio-economic development are shown in Table 6. The direct and indirect effect of the independent variables on socio-economic development is also presented in Table 7.

Table 6: Correlation matrix of the six significant characteristics

\begin{tabular}{|c|c|c|c|c|c|c|c|}
\hline & FS & GC & CRB & TE & AIN & ATP & $\begin{array}{c}\text { Correlation with } \\
\text { DV* }\end{array}$ \\
\hline FS & 1 & -0.052 & 0.061 & -0.048 & -0.001 & -0.028 & 0.111 \\
\hline GC & -0.052 & 1 & 0.322 & 0.112 & -0.037 & 0.415 & 0.315 \\
\hline CRB & 0.061 & 0.322 & 1 & 0.059 & 0.112 & 0.309 & 0.564 \\
\hline TE & -0.048 & 0.112 & 0.059 & 1 & 0.137 & 0.037 & 0.140 \\
\hline AIN & -0.001 & -0.037 & 0.112 & 0.137 & 1 & 0.003 & 0.161 \\
\hline ATP & -0.028 & 0.415 & 0.309 & 0.037 & 0.003 & 1 & 0.310 \\
\hline Path & 0.099 & 0.118 & 0.470 & 0.086 & 0.099 & 0.120 & \\
\hline
\end{tabular}

$\mathrm{DV}^{*}$ Dependent variable 
In fact, path co-efficient ' $p$ ' is an inherent correlation owned by the respondent in automatic manner. It is the direct effect of specific characteristic on the dependent variable and the indirect effects of other characteristics working in group are obtained by multiplying the column values of Table 6 by the ' $p$ ' of same column and the results are presented in Table 6.

Table 7: Direct and indirect effects of the characteristics on socio-economic development through PDBF activities

\begin{tabular}{|c|c|c|c|c|c|c|c|c|}
\hline & FS & GC & CRB & TE & AIN & ATP & $\begin{array}{c}\text { Corr. with } \\
\text { DV }(\mathbf{r})\end{array}$ & $\begin{array}{c}\text { Total indirect } \\
\text { effect }=\mathbf{r}-\mathbf{p}\end{array}$ \\
\hline FS & $\mathbf{0 . 0 9 9 0}$ & -0.0061 & 0.0287 & -0.0041 & -0.0001 & -0.0033 & 0.1111 & 0.0150 \\
\hline GC & -0.0051 & $\mathbf{0 . 1 1 8 0}$ & 0.1512 & 0.0096 & -0.0036 & 0.0498 & 0.3153 & 0.2019 \\
\hline CRB & 0.0061 & 0.0380 & $\mathbf{0 . 4 7 0 0}$ & 0.0050 & 0.0111 & 0.0370 & 0.5638 & 0.0972 \\
\hline TE & -0.0048 & 0.0132 & 0.0275 & $\mathbf{0 . 0 8 6 0}$ & 0.0135 & 0.0044 & 0.1403 & 0.0539 \\
\hline AIN & -0.0001 & -0.0043 & 0.0528 & 0.0117 & $\mathbf{0 . 0 9 9 0}$ & 0.0003 & 0.1606 & 0.0605 \\
\hline ATP & -0.0027 & 0.0490 & 0.1450 & 0.0031 & 0.0003 & $\mathbf{0 . 1 2 0 0}$ & 0.3100 & 0.1947 \\
\hline
\end{tabular}

The main diagonal elements (bold face) are direct effects and the off-diagonal elements are path-wise indirect effects and the row-wise sum of direct and indirect effects must be equal to the correlation co-efficient ' $r$ ' on socio-economic development through PDBF activities. The direct effect, 0.099 of family size (FS) raises to 0.111 at interaction with the group cohesion, credit repayment behavior, training exposure, adoption of innovations and attitude towards PDBF adding 0.0150 as total indirect effect of the correlation (r) on socioeconomic development through PDBF activities.

\section{Acknowledgement}

This study was conducted with the support from the Palli Daridro Bimochon Foundation (PDBF), Bangladesh. The authors are thankful to Department of Agricultural Extension \& Information System, Sere-eBangla Agricultural University, Dhaka and Department of Crop Science and Technology, University of Rajshahi, Bangladesh.

\section{Conclusion}

On the basis of the findings of the study it may be concluded that, 8 independent variables i.e. Family size, group cohesion, credit received, credit repayment behavior, training exposure, income generating activities, adoption of innovations and attitude towards PDBF were found significantly related with the dependent variable to increase their socio-economic conditions. Among of them, 6 independent variables i.e. family size, group cohesion, credit repayment behavior, training exposure, adoption of innovation and attitude towards PDBF jointly explained $37.90 \%$ of the total variation on change in socio-economic development. Out of this, $37.90 \%$ explained variance, the two independent variables i.e. credit repayment behavior and attitude towards PDBF contributed $34.10 \%$, signifying that these two are the most dominant contributing variables affecting contribution in socio-economic development. PDBF as a development organization of the country should consider this matter in their development policies to make their development strategies effective and successful.

\section{References}

[1]. Ahlin, C. and Jiang, N. (2008). Can microcredit bring development? Journal of Development Economics 86: 1-21.

[2]. Barboza, G. and Trejos, S. (2009). Micro Credit in Chiaps, Mexico: Poverty Reduction Trough Group Lending. Journal of Business Ethics, 88: 283-299.

[3]. Chowdhury, M. J. A., Ghosh, D. and Wright, R.E. (2005). Impact of micro-credit on poverty: evidence from Bangladesh; Progress in Development Studies, 5(4): 298-309.

[4]. Haque, M. A. and Harbin, J. L. (2009). Micro Credit: A different approach to traditional banking: Empowering the poor. Academy of Banking Studies Journal, 8(1): 1-13.

[5]. Hasan, M. M., Has0san, M. K and Uddin, M. R. (2009). Local Government Investment Outreach and Sustainability of Microfinance Institutions: A Case Study of BURO, Bangladesh. The Journal of Social, Political and Economic Studies, 34(3): 318346

[6]. Hashemi, S. M., Schuler, S. R and Riley, A. P. (1996). Rural Credit Programs and Women's Empowerment in Bangladesh. World Development, 24(4): 635-653.

[7]. Hossain, F. and Knight, T. (2008). Can microcredit improve the livelihoods of the poor and disadvantaged? Empirical observations from Bangladesh, IDPR 30(2): 155-175.

[8]. IFAD, (2012). Enabling poor rural people to overcome poverty in Bangladesh. Retrieved from $:\langle$ http://www.ifad.org/operations/projects/regions/PI/factsheets/bd.pdf $>$

[9]. Kabeer, N. (2001). Conflict over Credit: Re-Evaluating the Empowerment Potential of Loans to Women in Rural Bangladesh. World Development, 29(1): 63

[10]. Kotir, J. H. and Obeng-Odoom, F. (2009). Microfinance and rural household development a Ghanaian perspective. Journal of Developing Societies, 25(1): 85-105. 
[11]. Kotir, J. H. and Obeng-Odoom, F. (2009). Microfinance and rural household development a Ghanaian perspective. Journal of Developing Societies, 25(1): 85-105.

[12]. Mallick, R. (2002). Implementing and evaluating microcredit in Bangladesh. Development in Practice, 12(2): 153-241.

[13]. Mayoux, L. (1998). Women's empowerment and micro-finance programmes: strategies for increasing impact. Development in Practice ,8(2): 235-241.

[14]. Omorodion, F. I. (2007). Rural Women's Experiences of Microcredit Schemes in Nigeria: Case study of Asian Women. Journal of Asian and African Studies, 42(6): 479-494

[15]. Osmani, L. N. K. (2007). A breakthrough in women's bargaining power: The impact of microcredit. Journal of International Development, 19: 695-716.

[16]. Rahman, A. (1999). Microcredit Initiatives for Equitable and Sustainable Development: Who Pays? World Development, 27(1): 6782.

[17]. Sarker, A. S. and Rahman, M. H. (2007). The emerging perspective of governance and poverty alleviation: A case of Bangladesh Pub. Organiz. Rev., 7: 93-112.

[18]. Sultana, B., Zaaba, Z. B. and Umemoto, K. (2010). Women's Empowerment Through the Development of Micro Entrepreneurship in Rural Bangladesh. Soc. Sci., 5: 1-9. 